Article

\title{
Adaptation of Forest Management Regimes in Southern Sweden to Increased Risks Associated with Climate Change
}

\author{
Narayanan Subramanian ${ }^{1, *,+}$, Johan Bergh ${ }^{2, \dagger}$, Ulf Johansson ${ }^{3, \dagger}$, Urban Nilsson ${ }^{1,+}$ \\ and Ola Sallnäs 1
}

Received: 26 September 2015; Accepted: 21 December 2015; Published: 25 December 2015

Academic Editors: Jean-Claude Ruel and Eric J. Jokela

1 Southern Swedish Forest Research Centre, Swedish University of Agricultural Sciences (SLU), P.O. Box 49, SE-230 53 Alnarp, Sweden; Urban.Nilsson@slu.se (U.N.); Ola.Sallnas@slu.se (O.S.)

2 Department of Forestry and Wood Technology, Linnaeus University, SE-351 95 Växjö, Sweden; Johan.Bergh@Inu.se

3 Unit of Field-Based Forest Research, Swedish University of Agricultural Sciences (SLU), P.O. Box 17, SE-310 38 Simlångsdalen, Sweden; Ulf.Johansson@slu.se

* Correspondence: Narayanan.Subramanian@slu.se; Tel.: +46-40-41-5122; Fax: +46-40-46-2325

+ These authors contributed equally to this work.

\begin{abstract}
Even though the growth rates of most tree species in Sweden is expected to increase in the near future as a result of climate change, increased risks of damage by storms and various pests and pathogens, notably root rot and bark beetles, may also occur. Thus, forest management practices such as changes to thinning regimes, reductions in rotation lengths, and switching to other species (native or exotic) may represent adaptive management strategies to increase the resistance and resilience of Swedish forests to climate change. Clearly, thorough analyses examining the effects of anticipated climatic changes on damage levels, and the potentially relieving effects of possible management adaptations are needed before implementing such changes. In this study, damage caused by storms, root rot and bark beetles (single and in various combinations) under selected climate and management scenarios were simulated in Norway spruce (Picea abies (L.) Karst.) stands. The results indicate that reductions in thinning intensity and rotation lengths could improve both volume production and profitability in southern Sweden. In addition, cultivation of rapidly growing species, such as hybrid larch (Larix $\times$ marschlinsii Coaz.) and hybrid aspen (Populus tremula L. $\times$ P. tremuloides Michx.), could be as profitable as Norway spruce cultivation, or even more profitable. However, slow-growing species, such as Silver birch (Betula pendula Roth), Downy birch (Betula pubescens Ehrh.) and European beech (Fagus sylvatica L.) indicated low economic output in terms of Land Expectation Value.
\end{abstract}

Keywords: storm-felling; bark beetle; root rot; simulation model; forest production; profitability; land expectation value

\section{Introduction}

The forest industry in northern Europe is coniferous based and is of major economical and societal importance, since it provides jobs and income for forest owners and entrepreneurs as well as a whole range of forestry-related services. Norway spruce (Picea abies (L.) Karst.) and Scots pine (Pinus sylvestris L.) constitute more than $80 \%$ of the standing volume in Sweden [1]. In southern Sweden, Norway spruce forests dominate even more and if forestry continues as practiced today, the proportion of Norway spruce alone will exceed $60 \%$ within 30 years [2]. According to Bradshaw et al. [3], 
Norway spruce is currently grown outside its natural range in southern Sweden. These circumstances are not optimal from a risk perspective, especially in light of climate change, which brings elevated temperatures and a more uncertain weather pattern.

Climate observations show a temperature increase of $0.8^{\circ} \mathrm{C}$ since 1900 [4] and the latest climate change scenario projections for Europe suggest that by year 2100 mean surface temperature will increase by $4.8^{\circ} \mathrm{C}$ in northern Europe [5]. Projected climate change implies not only a change in mean climate parameters, such as temperature or precipitation, but also may result in changes in the frequency and magnitude of extreme weather events, such as frosts and storms [6,7].

Swedish forestry will have to adapt to meet the challenges associated with anticipated climate change. However, there are inevitably high levels of uncertainty in future climate scenarios, and effects of future climate change on forests are even more uncertain $[8,9]$. This severely complicates attempts to develop appropriate future silvicultural strategies. Nevertheless, several likely effects can be predicted with some confidence. For instance, process-based models consistently indicate that increases in temperatures and atmospheric $\mathrm{CO}_{2}$ levels will increase growth rates of forests in Nordic countries [9-12] and for Swedish forests by $15 \%-55 \%$ by the end of this century $[13,14]$, and that the strongest increases will be expected in northern Sweden. As a result of climate change, there is an increased opportunity to use new and more productive indigenous or exotic tree species in Swedish commercial forestry [15-17].

However, these potential benefits of a new climate should be weighed against increased risk of damage by pests, pathogens and storms [18]. Climate change might lead to increased frequency of storm events $[19,20]$ and increased temperatures may favor the introduction and spread of damaging pests and pathogens that have been previously limited by cold temperatures [21]. Of course, these effects will depend on responses of numerous, interacting components of ecosystems and food webs, e.g., host trees, pests and natural enemies [22-24]. Climate change may also cause systems to pass critical tipping points, which could massively increase their vulnerability to pests and pathogens.

Clearly, adaptive changes to forest management practices may be needed to meet anticipated changes and potential threats $[16,25]$. Chemical control measures and the development of efficient systems to monitor damage caused by pests and pathogens could be important. However, critical adjustments in southern Swedish forest management methods might be reducing the length of rotation periods and number of thinnings for Norway spruce, since stands are most vulnerable to storm damage after thinning and at old age [26]. Reducing the length of rotation periods and number of thinnings should also decrease the risk for root and butt rot (Heterobasidion annosum (Fr.) Bref.) infections, where the pathogen is more restricted to spread and reproduce in stands [27]. Even spruce bark beetle (Ips typographus L.) attacks could be reduced by reducing rotation periods, since they occur mainly in older stands [28]. A more drastic measure is to replace Norway spruce with broad-leaved tree species plantations such as Silver birch (Betula pendula Roth) and Downy birch (Betula pubescens Ehrh.) (hereafter, both will be referred to as birch), hybrid aspen (Populus tremula L. $\times$ P. tremuloides Michx.), hybrid larch (Larix $\times$ marschlinsii Coaz.) or European beech (Fagus sylvatica L.), which could reduce damage risks because they are less susceptible to root rot infections, bark beetle attacks and storm-felling. However, there are major uncertainties regarding all these hypothetical effects.

Many of the impacts of climate change may be decades ahead in the future but development and implementation of adaptation strategies in forestry might be necessary now [29], since the conversion of forests is a slow process due to long rotation periods. Most of these decisions have to be made without support from long-term studies. Therefore we should investigate short-term management strategies that can be applied in order to alleviate some of the vulnerabilities without compromising long-term management strategies [9,30,31]. Such analyses must consider the effects of adjustments on productivity, profitability, biodiversity, landscape aesthetics and social aspects of forests and damage risks.

This study analyzes effects on production, economy and risk of: (i) storm events, bark beetle attacks and root rot in a projected future climate in southern Sweden for Norway spruce stands; (ii) a 
changed thinning program and reduced rotation length for Norway spruce stands; and (iii) a change from Norway spruce to alternative tree species plantations. It should be noted that other effects of climate change on forest ecosystem variables, such as carbon storage and substitution effects, have not been taken into account.

\section{Material and Methods}

Site descriptions and starting values for simulations of stand growth were chosen in order to represent moderate to fertile site conditions in southern and central Sweden. Site index for Norway spruce was $34 \mathrm{~m}$ (dominant height at a total age of 100 years) [32]. For comparison of growth and economy of alternative species, site index $28 \mathrm{~m}$ for beech, $40 \mathrm{~m}$ for hybrid larch and $26 \mathrm{~m}$ (dominant height at 50 years) for birch were assumed to correspond to site index $34 \mathrm{~m}$ for Norway spruce [33-35].

\subsection{Growth Simulation Using Heureka-Standwise Model}

The analysis of Norway spruce growth was based on the stand growth simulations, using Heureka-Standwise, one of the models in the Heureka decision support system developed by Swedish University of Agricultural Sciences [36,37]. The Heureka-Standwise model forecasts growth and yields of forest stands from an early stage (about five years after planting) to final felling based on predicted five-year changes in the height and diameter of individual trees in circular plots with a $10 \mathrm{~m}$ radius. In this study, starting values at a dominant height of $9 \mathrm{~m}$ was calculated. Therefore, only mature stands were considered in this analysis. Two simulations were done for Norway spruce, one with high initial stocking and two thinnings and the second one with lower initial stocking without thinning (Table 1). Basal area of planted Norway spruce was estimated with basal area functions obtained from a spacing experiment [38]. Total age was estimated from height development functions [39]. Site characteristics were chosen to give a site index of $30 \mathrm{~m}$, which roughly corresponds to a top height of $34 \mathrm{~m}$ at a total age of 100 years.

Table 1. Forest management programs and tree species used in the simulations for the representative sites in southern Sweden. Site index is the average height of the 100 largest trees per ha at a total stand age of 100 years (50 years for birch). The letter in the site index indicates the site index species ( $\mathrm{G}=$ Norway spruce, $\mathrm{B}=$ Birch and $\mathrm{F}=$ European beech). The number in the site index shows the height $(\mathrm{m})$ the stand attains at an age of 100 years (50 years for birch). Initial stocking is the stand density $\left(\right.$ stems $\left.\cdot \mathrm{ha}^{-1}\right)$, MAI = Mean Annual volume Increment.

\begin{tabular}{cccccc}
\hline Tree Species & $\begin{array}{c}\text { Site Index, } \\
\text { m }\end{array}$ & $\begin{array}{c}\text { Initial } \\
\text { Stocking }\end{array}$ & $\begin{array}{c}\text { No. of } \\
\text { Thinnings }\end{array}$ & $\begin{array}{c}\text { Rotation } \\
\text { Length, Years }\end{array}$ & MAI, $\mathbf{~ m}^{\mathbf{3}} \cdot \mathbf{h a}^{-1}$ \\
\hline Norway spruce & G34 & 2000 & 2 & 65 & 12.7 \\
Norway spruce & G34 & 1500 & 0 & 45 & 11.5 \\
Birch & B22 & 1500 & 1 & 50 & 5.0 \\
European beech & F28 & 4000 & 5 & 105 & 7.9 \\
hybrid larch & G34 & 2000 & 3 & 35 & 12.9 \\
hybrid aspen & G34 & 1100 & 2 & 25 & $20.6 / 23.3$ \\
\hline
\end{tabular}

In the Heureka system, initial diameters of individual trees are simulated using Weibull-function [40]. Thereafter, heights of individual trees are estimated with functions developed by Söderberg [41]. Five-year basal area growth is estimated using a stand-level growth function for all trees in Sweden [42]. In parallel, five-year diameter-growth of individual trees is estimated using individual tree growth functions [42] but individual tree diameters are adjusted to sum up to the basal area calculated with the stand-level functions. Both these models are empirical based and generate growth according to variables describing the site (e.g., latitude, temperature sum, site index) and the stand (e.g., age, basal area and time since thinning, tree species composition). For the individual tree functions, variables describing the subject trees include, e.g., diameter, age and diameter in relation to diameter of larger trees. Growth functions and validation of those are described in Fahlvik et al. [36]. 
Potential height growth is modeled for individual trees with height growth functions for top-height trees [42]. Thereafter, height growth is reduced with a modifier depending on basal area of larger trees. Estimated individual tree diameter and height are used to calculate individual tree stem volumes according to volume functions [43]. Thereafter, individual tree stem volumes are summed up to per hectare values. Mortality is modeled in a two-step approach. First, average mortality per plot is modeled with a logistic function where basal area of larger trees, soil moisture, vegetation type and thinning history are important independent variables. In the second step, probability of mortality of individual trees is modeled with logistic functions [44] where basal area, individual tree diameter, thinning history and mean diameter are important independent variables.

\subsection{Implementation of Management in Heureka-Standwise Model for Norway Spruce Stand}

The reference management regimes implemented in Heureka-Standwise model were based on the current forest management programs for Norway spruce stands in Sweden. Forest management regimes were designed for Norway spruce dominated stands under current climate in southern Sweden, where site index was $34 \mathrm{~m}$. In accordance with prevailing practices, a site in southern Sweden with a site index of $34 \mathrm{~m}$ was established with 2000 seedlings. $\mathrm{ha}^{-1}$ ( 2500 seedlings. ha ${ }^{-1}$ are planted but 500 seedlings. ha ${ }^{-1}$ die within five years due to normal seedling mortality). The stand was subjected to two thinnings and clear cutting was done at an age of 65 years (Table 1). Thinnings and clear cutting were done according to standard thinning guides for Norway spruce in southern Sweden [45].

\subsection{Simulation of Risk Factors Associated with Climate Change for Norway Spruce Stand}

The major risk factors associated with climate change in Norway spruce dominated stands in southern Sweden, considered in this study were infection by root rot, spruce bark beetle damage and storm damage.

\subsubsection{Simulation of the Risk of Root Rot Infection Under Current Climate and Changing Climate}

The effects of four annual increases in the proportions of trees infected by root rot were considered in the simulations: $0.2 \%, 0.5 \%, 1 \%$ and $2 \%$ per year after the first thinning. A $0.2 \%$ annual increase in root rot infection roughly corresponds to current infection frequencies in southern Sweden [46], while the other growth rates correspond to potentially increased infection frequencies in a future climate that is more favorable to the spread and growth of root rot fungus. The root rot infection rate during the beginning of the observation period was $5 \%$ for Norway spruce stand [46]. The percentage of infected trees in the stand was calculated once every five years. The infected trees were assumed to be decayed up to an average trunk height of $3 \mathrm{~m}$.

\subsubsection{Simulation of the Risk of Spruce Bark Beetle Damage Under Current Climate and} Changing Climate

The effects of four annual increases in proportions of trees damaged by spruce bark beetles were included in the simulations: $0.1 \%, 0.2 \%, 0.3 \%$ and $0.4 \%$ per year. The increase of $0.1 \%$ per year was assumed to correspond to average current level in southern Sweden and the other growth rates correspond to potential increased damage frequencies in a future climate that is more favorable for the outbreak of bark beetles. The annual increase of $0.4 \%$ per year corresponds to levels recorded during the peak bark beetles attack year of 2006, following the major storm Gudrun in 2005. Only trees with a diameter at breast height $(\mathrm{dBH})$ larger than $20 \mathrm{~cm}$ were exposed to bark beetles damage [47]. The percentage of spruce bark beetle damage in the stand was calculated once every five years.

\subsubsection{Simulation of the Risk of Storm Damage Under Current Climate and Changing Climate}

The risk of storm damage was calculated using Persson's probability function relating the probability of trees damaged in a stand after a storm event to its top height [48]. The function was 
rescaled to match the probability of trees damaged in the stand after a storm event equivalent to that caused by storm Gudrun in 2005 in southern Sweden by adjusting the coefficient (Equation (1)). Yearly probabilities of storm damage were estimated for the simulated Norway spruce stand in southern Sweden with site index $34 \mathrm{~m}$ using the rescaled Persson's function. The proportion of trees damaged each year was calculated by multiplying the calculated storm damage probability with the proportion of undamaged trees in previous years (Equation (2)).

$$
P=H_{T}^{5} x
$$

where $P=$ Probability of storm damage, $H_{T}=$ Top height $(\mathrm{m})$, and $x=$ coefficient for rescaled function $=1.69 \times 10^{-8}$.

$$
P_{n}=P_{P}\left(1-\sum_{1}^{n-1} P_{S}\right)
$$

where $P_{n}=$ percentage of storm felled trees in a stand after nth storm event, $P_{P}=$ probability of storm damage in a stand after nth storm event calculated from Persson's function, and $P_{S}=$ percentage of trees damaged during previous storm events.

The effects of two storm scenarios were included in the simulations: a storm every 20th year and a storm every 5th year. In the storm every 20th year scenario, storms of Gudrun magnitude occur once every 20 years. Since the 1940s, three major storms events were recorded in Sweden, where volume of timber damaged after storm event was more than 10 million $\mathrm{m}^{3}[49,50]$. This shows that storms of Gudrun magnitude occur once every 20 years. Therefore, the storm every 20th year scenario roughly corresponds to the current storm intensity in southern Sweden. In the storm every 5th year scenario, storms of Gudrun magnitude occur once every five years. As a result of climate change, the frequency of storm events would increase in future in Sweden [19]. Therefore, the storm every 5 th year scenario would correspond to the potential increased frequency of storm events as an effect of changing climate. It should be noted that the function represents risks with the forest management regime prevailing in southern Sweden before the storm Gudrun and should not be used in conjunction with substantially different management practices.

\subsection{Sensitivity Analysis of Individual Risk Factors Based on Extent of Damage and Profitability of Norway Spruce Stand}

In a first step, analyses were performed to study effects of single types of damage on conventionally managed (Table 1) Norway spruce stand's growth and profitability. These analyses were considered a form of sensitivity analysis, indicating how critical the considered types of damage are for the LEV (Land Expectation Value). The profitability of the stand was calculated based on its LEV (Equation (3)). LEV is the perpetual sequence of identical rotations starting from bare land [51-53]. The annual discounted interest rate used in this study was $2.5 \%$.

In the economic calculations, average market prices for timber, pulpwood and energy wood assortments during the period 2000-2010 were used, while the costs of silvicultural and harvesting operations used were values for 2010 obtained from Swedish Forest Agency website [54]. The average market price for Norway spruce sawn timber and pulpwood were $45 € \cdot \mathrm{m}^{-3}$ and $26 € \cdot \mathrm{m}^{-3}$, respectively. The market price for European beech and birch pulpwood were $27 € \cdot \mathrm{m}^{-3}$ and 29 $€ \cdot \mathrm{m}^{-3}$, respectively. The average market price for hybrid aspen and hybrid larch pulpwood was $27 € \cdot \mathrm{m}^{-3}$. The cost of planting Norway spruce seedlings, birch and hybrid larch seedlings $(2500$ seedlings $\cdot \mathrm{ha}^{-1}$ ) was $1816 € \cdot \mathrm{ha}^{-1}$ (Table 2$)$. The Norway spruce seedlings $\left(1500 \mathrm{ha}^{-1}\right)$ were planted at a cost of $1282 € \cdot \mathrm{ha}^{-1}$. The cost of soil scarification for establishment of birch stand and European beech stand was $1282 € \cdot$ ha $^{-1}$. The cost of planting European beech seedlings was $1926 € \cdot$ ha $^{-1}$. Cost of pre-commercial thinning was $246 € \cdot \mathrm{ha}^{-1}$. The financial value for hybrid aspen stand was based on four 25-year rotations. The planting cost for first generation seedlings was $1816 € \cdot \mathrm{ha}^{-1}$. The fencing cost for hybrid aspen stand was $4272 € \cdot \mathrm{ha}^{-1}$, then the fence was removed in the second generation 
at a cost of $1068 € \cdot \mathrm{ha}^{-1}$. All four generations were pre-commercially thinned twice at a cost of 246 $€ \cdot$ ha $^{-1}$. The cost of harvesting operations was calculated based on cost curve, which was based on total volume and mean tree volume harvested. In the financial calculations, the value class of the root rot damaged timber was reduced from timber to pulpwood; the value-class of the bark beetle damaged trees was reduced from timber and pulpwood to bio-fuel. After the Gudrun storm event in 2005 , the value of storm-felled trees were reduced by $50 \%$ and the cost of harvesting operations were increased by $100 \%$ in Kronoberg county in Sweden [55]. Therefore, a similar pattern in timber price and harvesting cost were considered in the simulations here. The LEV was calculated when the stand attains an age of 42 years and the change in pattern of LEV was analyzed until the stand reached 87 years of age.

$$
\frac{L E V=\left[\sum_{n=0}^{t} R_{n}(1+i)^{-t}-\sum_{n=0}^{t} C_{n}(1+i)^{-t}\right] *(1+i)^{t}}{\left((1+i)^{t}-1\right)}
$$

where $L E V=$ Land Expectation Value, $i=$ annual discounted interest rate expressed as a decimal, $n=$ current age of the stand, $R_{n}=$ Revenue obtained during year $n, C_{n}=$ Cost incurred during year $n$, and $t=$ rotation length in years. LEVs for storm-damaged stands were calculated as the sum of LEVs of previous years storm damage plus LEV for the undamaged proportion at the year of calculation.

Table 2. Calculated volume productions and economic returns for Norway spruce, hybrid larch, hybrid aspen, European beech and birch stands in southern Sweden. The values for hybrid aspen are based on four 25-year rotation periods. Land expectation value (LEV) calculated using a $2.5 \%$ discounted interest rate. Cash flow is the movement of money (incomes minus costs) during the rotation without a discounted interest rate. MAI= Mean Annual volume Increment. G34-2 means a Norway spruce stand with site index 34 and two thinnings were done before final felling.

\begin{tabular}{|c|c|c|c|c|c|c|}
\hline & G34-2 & G34-0 & $\begin{array}{c}\text { Hybrid } \\
\text { Larch }\end{array}$ & $\begin{array}{c}\text { Hybrid } \\
\text { Aspen }\end{array}$ & $\begin{array}{c}\text { European } \\
\text { Beech }\end{array}$ & Birch \\
\hline Rotation length, years & 57 & 47 & 35 & $100(25 \times 4)$ & 105 & 50 \\
\hline Regeneration cost, $€ \cdot \mathrm{ha}^{-1}$ & 1816 & 1282 & 1816 & 7358 & 3204 & 1282 \\
\hline Total production, $\mathrm{m}^{3} \cdot \mathrm{ha}^{-1}$ & 683 & 524 & 453 & 2125 & 716 & 306 \\
\hline MAI, $\mathrm{m}^{3} \cdot \mathrm{ha}^{-1}$ & 13.5 & 11.2 & 12.9 & 21.2 & 6.8 & 5.1 \\
\hline Cash flow, $€ \cdot$ ha $^{-1} \cdot$ year $^{-1}$ & 310 & 299 & 278 & 352 & 278 & 132 \\
\hline LEV,$€ \cdot h^{-1}$ & 4518 & 4528 & 6013 & 6376 & 70 & 1314 \\
\hline
\end{tabular}

2.5. Simulation of Combined Effect of Various Risk Factors on Norway Spruce Stand Under Current Climate and Changing Climate

The combined effect of root rot infection, bark beetle damage and storm damage on a conventionally managed Norway spruce stand in southern Sweden was simulated under current climate and changing climatic conditions. Under the current climatic condition, it was assumed that the root rot infection would increase with an annual growth rate of $0.2 \%$; bark beetle damage would increase by an annual rate of $0.5 \%$; and storms of Gudrun magnitude would occur once every 20 years, whereas in changing climatic conditions, it was assumed that the root rot infection would increase with an annual growth rate of $1 \%$; bark beetle damage would increase by an annual rate of $1 \%$; and storms of Gudrun magnitude would occur once every five years. Apart from these, a baseline scenario named "No-damages" scenario was also considered. In the "No-damages" scenario, the stand was thinned according to the standard thinning guides. However, in this scenario, the risk factors such as root rot infection, bark beetle attacks and storm damage were not considered. The LEV of the Norway spruce stand under the "No-damages" scenario was calculated when the stand was 42 years old and the change in pattern of LEV was analyzed until the stand was 87 years old. Secondly, the corresponding storm damages were included in LEV calculation for current and changing climatic conditions. Then, the corresponding root rot infection rate and bark beetle damages were also included in LEV calculation. The percentage of trees infected or damaged by combined effect of storm 
damage, root rot infection and bark beetle damage under current and changing climate was calculated by summing their respective individual damages. The net income was then calculated with added damage levels, and finally LEV under a combined effect of various risk factors was calculated.

\subsection{Management Options in Adaptive Strategy to Reduce the Risk of Damages}

Two kinds of adaptive management strategies were considered in this study: (i) changing thinning regimes and reducing rotation length in Norway spruce stand; and (ii) switching to other suitable tree species instead of conventional Norway spruce cultivation.

\subsubsection{Changing Thinning Regimes and Reduction in Rotation Length of Norway Spruce Stand}

A modification of current forest management practices to decrease risks of damage due to wind-throw, root rot and bark beetles, was planting 1500 genetically improved Norway spruce seedlings. ha $^{-1}$. After mortality, tree density was assumed to be 1200 stems. ha ${ }^{-1}$ at a dominant height of $9 \mathrm{~m}$. The stand was not thinned in this simulation and finally felled at an age of 45 years.

\subsubsection{Simulation of Alternative Tree Species}

In operational forestry, two possible alternative hardwood tree species for these site conditions are birch and European beech. Potentially suitable exotic tree species for fertile sites in southern Sweden include hybrid larch and hybrid aspen. Development of birch, hybrid larch and European beech was estimated using their respective growth and yield tables [33-35]. Finally, an online program [56] was used for estimation of volume growth of hybrid aspen. For birch, European beech, hybrid larch and hybrid aspen, one alternative was simulated for each tree species and initial stocking and number of thinnings were chosen according to existing recommendations for all tree species (Table 1).

Birch stand was established by planting 2000 seedlings $\cdot$ ha $^{-1}$ after soil scarification, thinned once (at an age of 20 years) and harvested at an age of 40 years (Table 1). Volume in thinning and final harvest in birch stand was estimated according to Finnish yield table for Birch [35]. European beech stand was established after soil scarification and planting of 4000 seedlings. ha ${ }^{-1}$ under a low shelter of naturally regenerated birch (Table 1). After three pre-commercial thinnings, the low shelter was harvested and the European beech stand had a stand density of 1200 seedlings. ha ${ }^{-1}$ at an age of 25 years. The stand was thinned five times (age 40, 50, 60, 75 and 90 years) and was finally harvested at an age of 105 years. Volume in thinnings and final harvest were estimated according to Swedish yield tables for European beech [57].

Hybrid larch was established by scarification and planting of 2500 seedlings. $\mathrm{ha}^{-1}$. One pre-commercial thinning was done. Thereafter, the stand was thinned four times (age 15, 20, 25 and 30 years) and finally harvested at an age of 35 years. Volume in thinnings and final harvest of hybrid larch were estimated according to a Swedish yield table for hybrid larch [34]. Growth and management effects of hybrid aspen stand was simulated using a web-based simulation program [56]. This program is based on empirical functions developed for hybrid aspen stands in southern Sweden [58]. Variables necessary for running the program are type of regeneration method (planting or coppice), cost of regeneration, site index and proposed number of thinnings. The output variables obtained from the program are time of thinning and final felling, harvested volume during thinning and final felling. The hybrid aspen stand was established by planting 1100 seedlings. ha ${ }^{-1}$, with fencing to avoid severe browsing damage (Table 1). After two thinnings, the hybrid aspen stand was final harvested at an age of 25 years. The next generation of hybrid aspen was established from regenerated coppices, which are normally very plentiful. In the simulations, the coppice-generated hybrid aspen stand was pre-commercially thinned twice and then commercially thinned twice before final harvest, at an age of 25 years (which covered four generations of hybrid aspen).

It was generally assumed that browsing was controlled, so fencing was not required for Norway spruce stand establishment and the alternative tree species birch, European beech and hybrid larch. 


\section{Results}

\subsection{Root Rot Infection and Its Effect on Land Expectation Values}

With the highest studied infection rate ( $2 \%$ per year), all trees were infected by root rot at a stand age of 77 years (Figure $1 \mathrm{~A}$ ). An increase in the frequency of infected trees by $0.2 \%$ per year, on average, resulted in an infection intensity of $7 \%-12 \%$ in stand at final felling (depending on final felling age). A growth rate of $1 \%$ per year resulted in $35 \%-40 \%$ of trees being infected at final felling time.

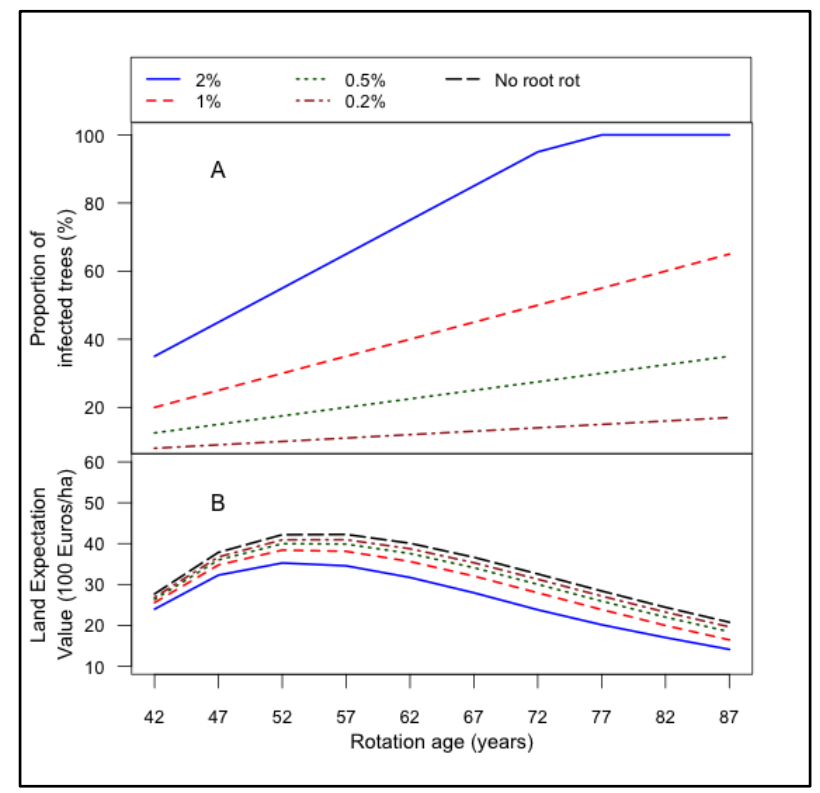

Figure 1. Changes in proportions of infected trees at final felling (A); and land expectation values (B); with stand age and indicated annual increases in root rot infection rates in the Norway spruce stand in southern Sweden.

The land expectation value of the undamaged forest peaked at 55 years and the increase in damage by root rot of $<1 \%$ per year did not significantly change the peak time (Figure $1 \mathrm{~B}$ ). In the scenario with a $1 \%$ growth rate, the land expectation value remained constant between 52 and 57 years of age, while it peaked at 52 years for the scenario with a $2 \%$ annual increase. With an increase in the root rot infection rate to $1 \%$ per year, the land expectation value was $7 \%$ to $20 \%$ lower compared to the scenario with no damage (depending on rotation period).

\subsection{Bark Beetle Attacks and Its Effect on Land Expectation Values}

An annual increase of $0.4 \%$ in the proportion of trees damaged by the insect resulted in $10 \%-18 \%$ affected trees at the final felling (Figure 2A). In the reference simulations, it was assumed that damage caused by bark beetles typically increased by $0.1 \%$ per year, resulting in $2.5 \%-4 \%$ of the timber volume being damaged (depending on the final felling age; Figure 2A). The land expectation value peaked at 52-57 years in the absence of bark beetle attacks. The current assumed level of bark beetle damage resulted in only a marginal reduction of land expectation value (Figure 2B). An increase in proportion of trees damaged by bark beetle from the current level to $0.3 \%$ resulted in an earlier culmination of land expectation value and the peak value was reduced by $8 \%$ when compared to the scenario without bark beetle damage. 


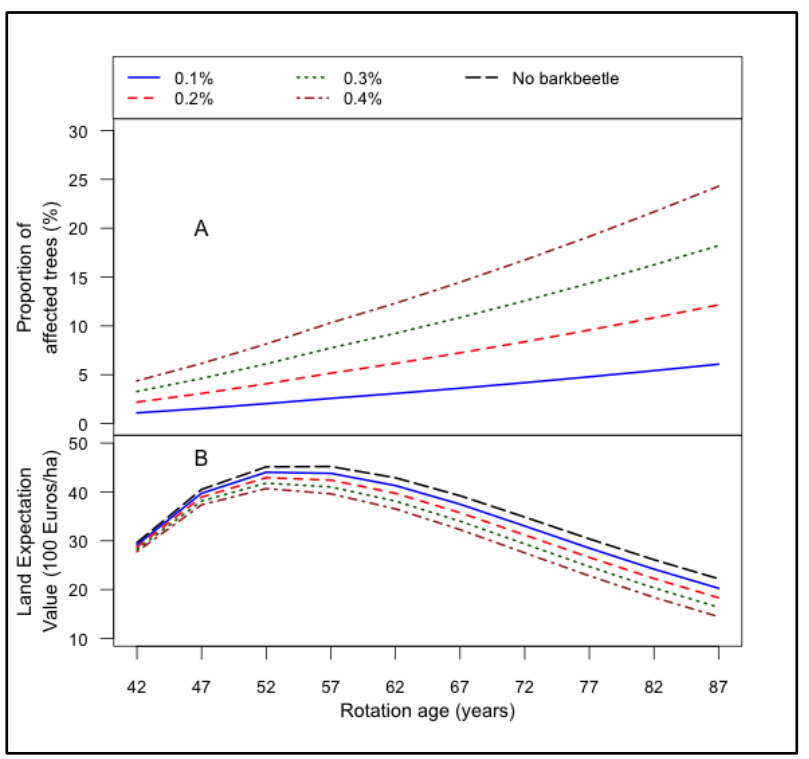

Figure 2. Percentage of standing volumes affected by bark beetle damage at final felling in Norway spruce stand in southern Sweden with indicated annual increases in damage levels (A). Changes in land expectation values with rotation age, with indicated annual increases in levels of bark beetle damage in Norway spruce stand in southern Sweden (B).

\subsection{Major Storms and Their Effects on Land Expectation Value}

If major storm-fellings arbitrarily affected Norway spruce stand once every fifth year, almost no trees would reach an age of 87 years (Figure 3A). If the occurrence of storms were once every 20 years in the Norway spruce stand, $60 \%$ of the volume would be storm-felled at a rotation age of 87 years. If storms of Gudrun's magnitude occurred in southern Sweden once every fifth year, the land expectation value would be reduced by $20 \%$ with 57 -year rotations, and the corresponding reduction if such storms occurred once every 20 years would be approximately $6 \%$ (Figure 3B). Both storm frequencies resulted in an earlier peak of the land expectation value compared to the "No-storm" scenario. The optimal final felling age was reduced from 57 years for the scenario with no storm damage to 52 years for the scenarios including effects of storm damage. For long rotation periods, land expectation value is higher for the higher frequency of storms. This is due to the fact that the net present value of final felling at very long rotation periods will become relatively low, while the value of past storm-felled forest result in higher net present value, since these incomes occur earlier during the rotation period. The increase in storm-felled volume late in the rotation period is also higher for the lower frequency of storms than for the higher frequency because a large proportion of the volume has already been felled if storms are as frequent as every five years.

\subsection{Combined Effects of Root Rot, Bark Beetle and Major Storms on Land Expectation Values}

The combined effect of root rot, bark beetle and storms with current damage level reduced the LEV by $13 \%$ (Figure 4), when compared to the "No-damages" scenario at a rotation age of 57-years. The peak of the LEV was affected if damage from storms, root rot and bark beetle were included in the analysis. For the "No-damages" scenario the land expectation value peaked at 57 years. When the damages were allowed to influence the stand development the LEV peaked five years earlier at 52 years. 


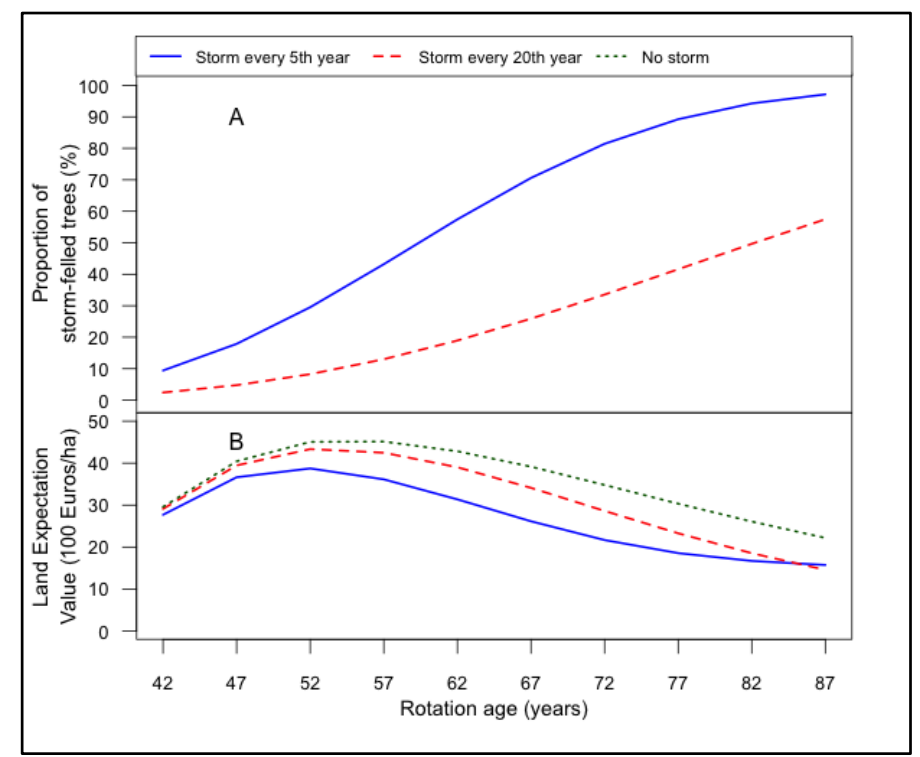

Figure 3. Storm-felled stem volumes, as proportions of total stem volumes (A); and land expectation values (B); if a major storm with the magnitude of Gudrun occurred never, once every fifth year and once every 20th year in Norway spruce stand in southern Sweden.

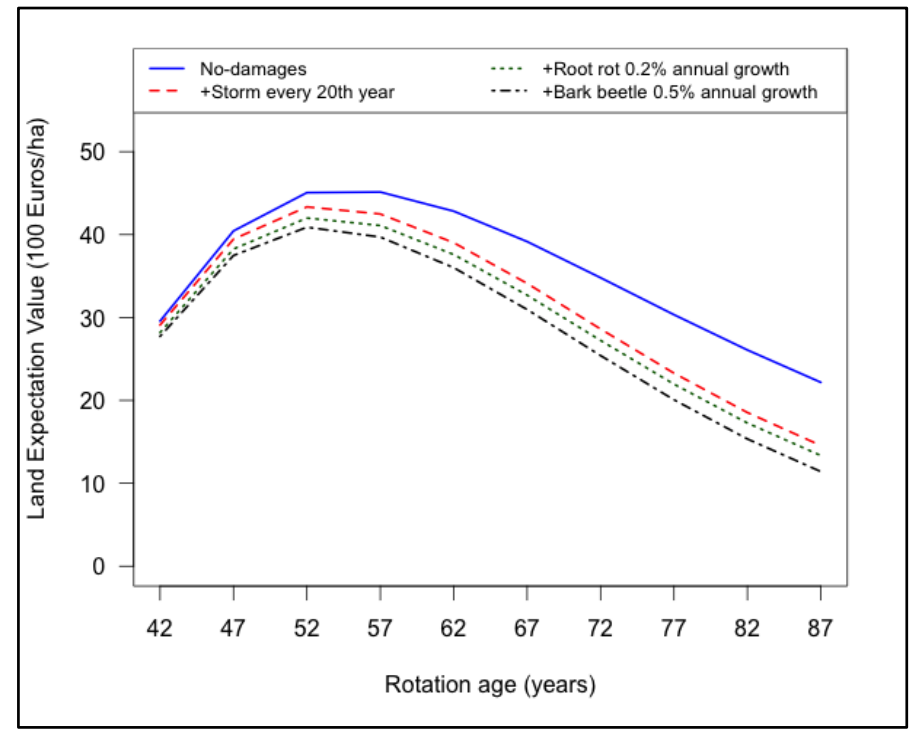

Figure 4. Land expectation values for Norway spruce stand $\left(\mathrm{SI}=\mathrm{G} 34^{*}\right)$ in southern Sweden under "No-damages" scenario and adding the risk factors such as storm damage, root rot infection and bark beetle damage to the "No-damages" scenario in current climate. * The letter represents site index species, $G=$ Norway spruce, and the number in the site index shows the height $(\mathrm{m})$ the stand attains at an age of 100 years.

The increases in all three considered major risk factors (root rot, bark beetle and storm-felling) due to anticipated climate change reduced the land expectation value, at an age of 57 years, by about $42 \%$ from 4514 ("No-damages" scenario) to $2614 € \cdot \mathrm{ha}^{-1}$ (Figure 5). Increases in damage levels also resulted in significant reductions of the peak land expectation value, which occurred five years earlier than in the "No-damages" scenario under a changing climate. 


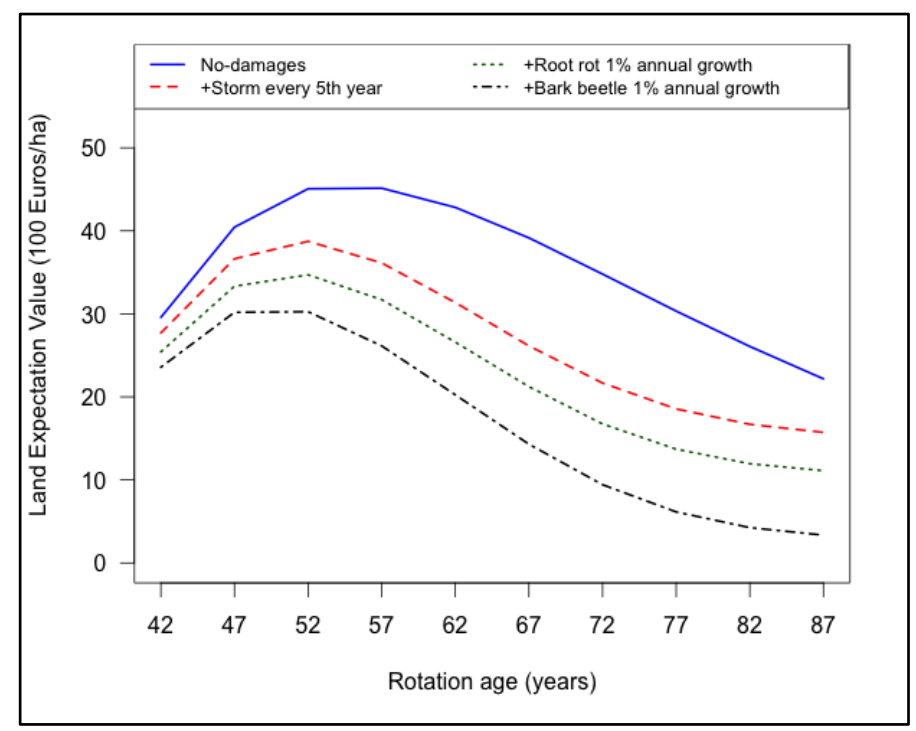

Figure 5. Land expectation values for Norway spruce stand in southern Sweden $\left(\mathrm{SI}=\mathrm{G} 34^{*}\right)$ under "No-damages" scenario and adding the risk factors such as storm damage, root rot infection and bark beetle damage to "No-damages" scenario under a changing climate. * The letter represents site index species, $G=$ Norway spruce, and the number in the site index shows the height $(\mathrm{m})$ the stand attains at an age of 100 years.

\subsection{Alternative Management Programs and Land Expectation Values}

Economic calculations indicate that European beech and birch plantations would provide lower volume production and be less profitable compared to plantations of other tree species (Table 2). In contrast, both hybrid aspen and hybrid larch plantations would apparently be at least as profitable as Norway spruce cultivation. Hybrid aspen stand also provided substantially higher volume production than Norway spruce stand, but with higher establishment costs (Table 2).

\section{Discussion}

One of the major factors that facilitate the increasing intensity of risk factors on a Norway spruce stand is management activity like thinning $[26,59,60]$. Soon after a thinning operation Norway spruce stands are particularly more vulnerable to root rot infection and storm damage. The basidiospores of root rot fungus spreads through freshly cut stump surfaces and wounds soon after thinning activity [61]. The fungal mycelium also spreads through root contacts and thus infects the neighboring healthy trees [59]. Thus, soon after a thinning activity in Norway spruce stand, the stand is well exposed to root rot fungal spores and the infection could also spread to second generation healthy stands through root contacts. As the intensity of thinning activity increases, there would be a higher number of freshly cut stump surfaces available in the stand for root rot fungus to infect and thus increasing the intensity of infection. The risk of storm damage in a recently thinned Norway spruce stand is high and the extent of storm damage is linearly related to the intensity of thinning [26]. This is because the trees that remain after thinning are more vulnerable to storm damage due to lack of mutual support from neighboring trees and wider spacing resulting from thinning [26]. Large-scale outbreaks of bark beetles are often associated with warmer temperatures and insufficient soil water supply. Outbreaks often occur after major storm events [62]. Since the storm damage is directly linked with thinning intensity, bark beetle damage is also indirectly related to increasing thinning intensity.

An infection rate of root rot by $2 \%$ per year is extremely unusual in Norway spruce stands today with prevailing forest management regimes. The scenario with an increased frequency of infected trees by $0.2 \%$ is more consistent with current rates of root rot spread [63]. Climate change might lead to higher infection intensities, due to the faster growth of the fungi in warmer conditions and 
extension of the period when spores can spread and infect newly cut fresh stumps. It is very difficult to quantify the impact of climate change on the rate of spreading and growth of root rot, due to uncertainties regarding effects of numerous associated changes in both biotic and abiotic factors. However, we can assume that a $2 \%$ annual increase in frequencies of damaged trees is unlikely because such high rates have been recorded very rarely in Norway spruce forests in southern Sweden. A growth rate of 1\% per year corresponds to the level in the stands that are most severely damaged by root rot today, which might be a possible future scenario.

The simulation with $0.2 \%$ annual increase in the root rot infections resulted in $3.2 \%-4.6 \%$ reduction in land expectation value at final felling (Table 1 ). However, this was an unexpectedly small effect because more than $10 \%$ of the trees were infected at final felling in the current situation. This low effect was because root rot was assumed to affect only the bottom $3 \mathrm{~m}$ of the trunk, accounting for about $20 \%$ of the volume for a stem with $30 \mathrm{~cm} \mathrm{dBH}$. Moreover, wood damaged by root rot can be used commercially, although the value drops from timber to firewood prices, and the damage mainly affected the values at the end of the rotation period when it would have the least impact on net present and land expectation values. Even though the impact of root rot infection on LEV of Norway spruce stands is rather small in the current situation, it could lead to increased risk in the future in a changing climate. If the rates of root rot infection increases under a changing climate, then the land expectation value will reduce significantly and require more costly measures to minimize its spread in the future if no control measures were undertaken in the near future.

The major storm-felling in 2005 in southern Sweden caused an increase in bark beetle population and major subsequent damage to forest stands [64]. Although the damage was mitigated by various countermeasures, it was high in 2006 due to the abundance of breeding material for the bark beetles and prevalence of weather conditions that allowed the reproduction of two bark beetle generations during the same season [64]. The spruce bark beetle in southern Sweden damaged approximately $1 \%-1.5 \%$ of the standing volume of trees with a diameter larger than $20 \mathrm{~cm}$, which corresponds roughly to 1.5 million $\mathrm{m}^{3}$ of wood. However, this scenario (Figure 2A) is considered a very high damage level because it assumes that the level of damage recorded in 2006 would be repeated every year. The current level of bark beetle damage cannot be estimated in the same way as for root rot, as the mechanism of spreading of bark beetles is different from spreading of root rot fungus. The annual increase in bark beetle damage is much lower than the annual increase in root rot infection. However, if the level of bark beetle damage increases in the future due to climate change, its impact on land expectation value would also increase and the impact would be larger for longer rotation periods, similar to the effect of root rot infection. Thus, an increase in spruce bark beetle attack would result in an earlier culmination of the MAI. The final felling age would be five years lower for the alternative with a $0.4 \%$ annual increase in bark beetle damage compared to the undamaged scenario. As the annual rate of spread of bark beetles increases, the peak LEV culminates earlier (Figure 2B). However, under a changing climate, the spread of bark beetle will increase thus resulting in major reduction in LEV of Norway spruce stand in future. Therefore, it is important to undertake counter measures against spread of bark beetles in the near future. If not, it might be necessary to undertake more intense counter measures in future, which might be costly. These results of the combined effects of root rot infections, bark beetle attacks and storm damages indicate that forest management strategies should be changed in the future. Indeed, some changes have already been implemented in southern Sweden. Notably, after storm Gudrun, recommended forestry management practices have shifted towards earlier and fewer thinnings and as well as shorter rotation periods.

This analysis shows that the risk of bark beetle damage and root rot infection increased with time due to cumulative spreading of root rot fungus and bark beetle insects. The risk of storm damage increases with increase in stand height [65] which also increases with stand age. Therefore, the sensitivity of Norway spruce stands to risk factors is high in conventional management with 65 years of rotation (Table 1). Thus, implementing forest management programs with shorter rotation periods, providing earlier peaks of financial value, could provide a pro-active way to reduce risks of damage. 
Thus, stopping thinning and reducing rotation periods in Norway spruce cultivation could increase profitability (Table 3). However, the drawbacks of a forest management regime without thinning must also be considered, such as the risk for increased natural mortality, risk of snow damage [66,67] and the lack of both selection opportunities and early incomes from thinnings. Furthermore, in such a regime, the cost of planning would be less due to wider initial spacing (Table 1), however there might be negative effects on future wood quality due to the lack of selection [68]. Therefore, financial benefits of a thinning free management regime could be smaller than expected. Another management option to reduce damage risks is to replace damaged conifer stands with stands of species that are either less susceptible to damage or have shorter rotation periods such as European beech, birch, hybrid aspen and hybrid larch.

Table 3. Various adaptation strategies considered in this study and their pros and cons.

\begin{tabular}{|c|c|}
\hline Pros & Cons \\
\hline \multicolumn{2}{|c|}{ Avoid thinning and reducing rotation length } \\
\hline $\begin{array}{l}\text { - } \quad \text { Less exposure of stand to root rot fungus } \\
\text { - } \quad \text { Reduced risk of storm damage due to } \\
\text { increased stand density }\end{array}$ & $\begin{array}{l}\text { - } \quad \text { Increased risk of natural mortality in stand } \\
\text { - } \quad \text { Lack of early income from thinning } \\
\text { - } \quad \text { Lack of selection opportunity of future crop }\end{array}$ \\
\hline \multicolumn{2}{|c|}{ Switching to other native species } \\
\hline $\begin{array}{l}\text { - Less susceptible to root rot, storm damage } \\
\text { and bark beetle }\end{array}$ & - Less profitable when compared to Norway spruce \\
\hline \multicolumn{2}{|c|}{ Switching to exotic tree species } \\
\hline $\begin{array}{l}\text { - Less susceptible to root rot and bark } \\
\text { beetle infection }\end{array}$ & $\begin{array}{l}\text { - High risk of storm damage } \\
\text { - } \quad \text { Uncertainty regarding potential invasion, pest } \\
\text { and diseases }\end{array}$ \\
\hline
\end{tabular}

The silvicultural programs for stands of hybrid larch and hybrid aspen included in the analyses indicate that the height of the trees in later parts of the rotations would exceed $25 \mathrm{~m}$, thus the theoretical risk of storm would be high (Table 3). However, both species are defoliated during the winter time so the risk of storm damage is less compared to Norway spruce stands. Hybrid larch is highly susceptible to infection by root rot [69] and should not be planted after clearing infected stands. The risk for spruce bark beetle damage is low for these species, but other pests and pathogens that are not considered here and also the risk of invasion might pose potential future problems.

This analysis shows that appropriate adaptations of forest management programs and changing tree species can reduce the risks for damage from storms, root rot and bark beetles. It is also possible to make these adjustments without excessive productivity or financial losses. Climate change is expected to increase the volume production of the forests by a degree corresponding to an increase in site index by $4 \mathrm{~m}$ by the end of the current century [13]. Though boreal Swedish forest might benefit in a future changing climate, it must also be taken in to account that the potential uncertainty due to risk factors might also increase under a changing climate.

The reported analyses focused on risks for damage from storms, root rot and bark beetles. However, there are high uncertainties regarding numerous other factors that may influence both climate change and its effects on forests in the future. For example, climate change might also affect risks for damage by agents such as summer frosts, pine weevils and forest fires. To reduce risks for such damage, other adaptive forest management methods must be thoroughly addressed, and might conflict with the measures discussed here for adapting to changes in risks posed by storms, root rot and bark beetles. For example, thinning free management practice might reduce risk of storms, root rot and bark beetles. However, it might increase the risk of forest fire and snow damage in the forest stand. Results from this analysis could be included in underlying assumptions about the future scenario drivers of various factors. Predictions of forest growth and yield models could be improved by including these risk factors in their simulations. Thus, before implementing possible 
counter-measures uncertainties due to risk factors must be carefully considered and a rigorous cost-effective, flexible, adaptive risk management strategies must be formulated.

\section{Conclusions}

The main conclusions of this study are:

- Damages caused by storms, root rot and bark beetle resulted in reduction of LEV.

- The LEV peaked earlier at high damage levels of root rot ( $2 \%$ growth in annual infection rate), bark beetle ( $0.3 \%$ growth in annual damage rate) and storms.

- Even though the impact of root rot infection and bark beetle damage on LEV of Norway spruce stand is minimal under current infection rate, it is important to implement counter measures now, because in future the infection rate of these risk factors would increase and then more intense counter measures might require which would be costly.

- Avoiding thinning and reducing the rotation length in Norway spruce stands in southern Sweden could reduce the risk of damages due to root rot, storm and bark beetle as the intensity of risk factors increased with age of the stand and soon after thinning operation.

- Switching to other fast growing tree species plantations such as hybrid-larch and hybrid-aspen in southern Sweden were at least as profitable as Norway spruce whereas switching to slow growing species such as birch and European beech gave considerably lower economic compared to Norway spruce.

Based on the results of the study, it is evident that the risk factors associated with future climate will have tremendous impact on the forestry sector, unless counter-measures are undertaken in the near future. From a landscape perspective and in the long-term, appropriate adaptation strategies such as reduced thinning and shortening of rotation length in Norway spruce stands or switching to other plausible tree species instead of Norway spruce, are important alternatives for counter-measures. Moreover, the results of this study could be valuable input in formulating future scenarios on risk factors under a changing climate.

Acknowledgments: Future Forests, a multi-disciplinary research program supported by the Foundation for Strategic Environmental Research (MISTRA-SWECIA), financed this study.

Author Contributions: Ola Sallnäs, Ulf Johansson, Urban Nilsson and Johan Bergh initially planned the study and performed the literature review; Urban Nilsson ran the simulations with the Heureka-Standwise model and analyzed the results; and Johan Bergh and Narayanan Subramanian wrote the article.

Conflicts of Interest: The authors declare no conflict of interest.

\section{References}

1. SLU. Historical Data from National Forest Inventory. Swedish National Forest Inventory. Swedish University of Agricultural Sciences. Available online: http://www.slu.se/en/collaborative-centresand-projects/swedish-national-forest-inventory/historical-data/ (accessed on 1 October 2013).

2. Claesson, S. Skogliga Konsekvensanalyser 2008-SKA-VB 08 (Impact Assessment in Forestry 2008); Skogsstyrelsen (Swedish Forest Agency) Rapport 25; Swedish Forest Agency: Jönköping, Sweden, 2008. (In Swedish)

3. Bradshaw, R.H.; Holmqvist, B.H.; Cowling, S.A.; Sykes, M.T. The effects of climate change on the distribution and management of Picea abies in southern Scandinavia. Can. J. For. Res. 2000, 30, 1992-1998. [CrossRef]

4. Stocker, T.; Qin, D.; Plattner, G.; Tignor, M.; Allen, S.; Boschung, J.; Nauels, A.; Xia, Y.; Bex, B.; Midgley, B. IPCC, 2013: Climate Change 2013: The Physical Science Basis; Working Group I to the Fifth Assessment Report of the Intergovernmental Panel on Climate Change; Cambridge University Press: Cambridge, UK; New York, NY, USA, 2013. 
5. Intergovernmental Panel on Climate Change (IPCC). Summary for Policymakers. In Climate Change 2013: The Physical Science Basis; Stocker, T.F., Qin, D., Plattner, G.K., Tignor, M., Allen, S.K., Boschung, A., Nauels, Y., Xia, Y., Bex, V., Midgley, P.M., Eds.; Working Group I to the Fifth Assessment Report of the Intergovernmental Panel on Climate Change; Cambridge University Press: Cambridge, UK; New York, NY, USA, 2013.

6. Blennow, K.; Olofsson, E. The probability of wind damage in forestry under a changed wind climate. Clim. Chang. 2008, 87, 347-360. [CrossRef]

7. Jungqvist, G.; Oni, S.K.; Teutschbein, C.; Futter, M.N. Effect of climate change on soil temperature in Swedish boreal forests. PLOS ONE 2014, 9, e93957. [CrossRef] [PubMed]

8. Smith, B.; Knorr, W.; Widlowski, J.L.; Pinty, B.; Gobron, N. Combining remote sensing data with process modelling to monitor boreal conifer forest carbon balances. For. Ecol. Manag. 2008, 255, 3985-3994. [CrossRef]

9. Kellomäki, S.; Peltola, H.; Nuutinen, T.; Korhonen, K.T.; Strandman, H. Sensitivity of managed boreal forests in Finland to climate change, with implications for adaptive management. Philos. Trans. R. Soc. Lond. B Biol. Sci. 2008, 363, 2339-2349. [CrossRef] [PubMed]

10. Bergh, J.; Freeman, M.; Sigurdsson, B.; Kellomaki, S.; Laitinen, K.; Niinisto, S.; Peltola, H.; Linder, S. Modelling the short-term effects of climate change on the productivity of selected tree species in Nordic countries. For. Ecol. Manag. 2003, 183, 327-340. [CrossRef]

11. Koca, D.; Smith, B.; Sykes, M.T. Modelling regional climate change effects on potential natural ecosystems in Sweden. Clim. Chang. 2006, 78, 381-406. [CrossRef]

12. Pussinen, A.; Nabuurs, G.; Wieggers, H.; Reinds, G.; Wamelink, G.; Kros, J.; Mol-Dijkstra, J.; de Vries, W. Modelling long-term impacts of environmental change on mid-and high-latitude European forests and options for adaptive forest management. For. Ecol. Manag. 2009, 258, 1806-1813. [CrossRef]

13. Bergh, J.; Linder, S. Skogsbruket måste påbörja omställningen (Conversion should Begin in Forest Management). In Formas Fokuserar "Sverige i ett nytt Klimat-Våtvarm Utmaning" (Formas Focuses_-Sweden in a New Climate-Wet-Warm Challange"); Swedish National Forest Inventory (SLU): Alnarp, Sweden, 2010.

14. Subramanian, N. Simulation of Net Primary Production (NPP) of Picea Abies in Southern Sweden: An Analysis Based on Three Forest Growth Models; Swedish University of Agricultural Science: Alnarp, Sweden, 2010; p. 43.

15. Bolte, A.; Ammer, C.; Löf, M.; Madsen, P.; Nabuurs, G.-J.; Schall, P.; Spathelf, P.; Rock, J. Adaptive forest management in central Europe: Climate change impacts, strategies and integrative concept. Scand. J. For. Res. 2009, 24, 473-482. [CrossRef]

16. Mason, W.; Petr, M.; Bathgate, S. Silvicultural strategies for adapting planted forests to climate change: From theory to practice. J. For. Sci. 2012, 6, 265-277.

17. Meason, D.F.; Mason, W.L. Evaluating the deployment of alternative species in planted conifer forests as a means of adaptation to climate change-case studies in New Zealand and Scotland. Ann. For. Sci. 2014, 71, 239-253. [CrossRef]

18. Blennow, K.; Eriksson, H.M.; Skogsstyrelsen, S. Riskhantering i Skogsbruket. (Risk Handling in Forestry); Rapport 14; Skogsstyrelsen: Jönköping, Sweden, 2006; p. 51.

19. Blennow, K.; Andersson, M.; Bergh, J.; Sallnas, O.; Olofsson, E. Potential climate change impacts on the probability of wind damage in a south Swedish forest. Clim. Chang. 2010, 99, 261-278. [CrossRef]

20. Clark, A.J. Climate. The changing climatic environment for New Zealand's land-based sectors. In Impacts of Climate Change on Land-Based Sectors and Adaptation Options; Clark, A., Nottage, R., Wilcocks, L., Lee, J., Burke, C., Kalaugher, E., Roche, J., Beukes, P., Lieffering, M., Newton, P., Eds.; Stakeholder Report to the Sustainable Land Management and Climate Change; Ministry for Primary Industries: Wellington, New Zealand, 2012.

21. Dukes, J.S.; Pontius, J.; Orwig, D.; Garnas, J.R.; Rodgers, V.L.; Brazee, N.; Cooke, B.; Theoharides, K.A.; Stange, E.E.; Harrington, R. Responses of insect pests, pathogens, and invasive plant species to climate change in the forests of northeastern North America: What can we predict? Can. J. For. Res. 2009, 39, 231-248. [CrossRef]

22. Björkman, C.; Bylund, H.; Klapwijk, M.J.; Kollberg, I.; Schroeder, M. Insect pests in future forests: More severe problems? Forests 2011, 2, 474-485. [CrossRef] 
23. Stenlid, J.; Oliva, J.; Boberg, J.B.; Hopkins, A.J. Emerging diseases in European forest ecosystems and responses in society. Forests 2011, 2, 486-504. [CrossRef]

24. Klapwijk, M.J.; Ayres, M.P.; Battisti, A.; Larsson, S. Assessing the impact of climate change on outbreak potential. In Insect Outbreaks Revisited; Wiley-Blackwell: Hoboken, NJ, USA, 2012; pp. 429-450.

25. Keenan, R.J. Adaptation of forests and forest management to climate change: An editorial. Forests 2012, 3, 75-82. [CrossRef]

26. Wallentin, C.; Nilsson, U. Storm and snow damage in a Norway spruce thinning experiment in southern Sweden. Forestry 2014, 87, 229-238. [CrossRef]

27. Möykkynen, T.; Miina, J.; Pukkala, T. Optimizing the management of a Picea abies stand under risk of butt rot. For. Pathol. 2000, 30, 65-76. [CrossRef]

28. Martikainen, P.; Siitonen, J.; Kaila, L.; Punttila, P.; Rauh, J. Bark beetles (Coleoptera, Scolytidae) and associated beetle species in mature managed and old-growth boreal forests in southern Finland. For. Ecol. Manag. 1999, 116, 233-245. [CrossRef]

29. Lindner, M.; Maroschek, M.; Netherer, S.; Kremer, A.; Barbati, A.; Garcia-Gonzalo, J.; Seidl, R.; Delzon, S.; Corona, P.; Kolström, M.; et al. Climate change impacts, adaptive capacity, and vulnerability of European forest ecosystems. For. Ecol. Manag. 2010, 259, 698-709. [CrossRef]

30. Bodin, P.; Wiman, B.L. The usefulness of stability concepts in forest management when coping with increasing climate uncertainties. For. Ecol. Manag. 2007, 242, 541-552. [CrossRef]

31. Spittlehouse, D.L. Climate Change, Impacts, and Adaptation Scenarios: Climate Change and Forest and Range Management in British Columbia; Ministry of Forests and Range: Victoria, BC, Canada, 2008.

32. Elfving, B.; Kiviste, A. Construction of site index equations for Pinus sylvestris L. using permanent plot data in Sweden. For. Ecol. Manag. 1997, 98, 125-134. [CrossRef]

33. Carbonnier, C. Yield of Beech in Southern Sweden; Institution för Skogsproduktion: Stockholm, Sweden, 1971; pp. 1-89. (In Swedish)

34. Ekö, P.M.; Stern, M.L.; Albrektson, A. Growth and yield of hybrid larch (Larix $\times$ eurolepis A. Henry) in Southern Sweden. Scand. J. For. Res. 2004, 19, 320-328. [CrossRef]

35. Oikarinen, M. Etelä-Suomen Viljeltyjen Rauduskoivikoiden Kasavatusmallit (Growth and Yield Models for Silver Birch (Betula Pendula) Plantations in Southern Finland); The Finnish Forest Research Institute: Helsinki, Finland, 1983; Volume 113, p. 75.

36. Fahlvik, N.; Wikström, P.; Elfving, B. Evaluation of growth models used in the Swedish Forest Planning System Heureka. Silva Fenn. 2014, 48, 1-17. [CrossRef]

37. Wikström, P.; Edenius, L.; Elfving, B.; Eriksson, L.O.; Lämås, T.; Sonesson, J.; Öhman, K.; Wallerman, J.; Waller, C.; Klintebäck, F. The Heureka Forestry Decision Support System: An Overview. Math. Comput. For. Nat. Resour. Sci. 2011, 3, 87-95.

38. Pettersson, N. The Effect on Stand Development of Different Spacing after Planting and Precommercial Thinning in Norway Spruce (Picea abies (L.) Karst.) and Scots Pine (Pinus sylvestris L.) Stands; Rapport-Sveriges Lantbruksuniversitet; Swedish University of Agricultural Sciences: Uppsala, Sweden, 1992.

39. Elfving, B. Övre Höjdens Utveckling i Granplanteringar (Top Height Growth in Norway Spruce Plantations); Department of Silviculture, Swedish University of Agricultural Sciences: Uppsala, Sweden, 2003; p. 8. (In Swedish)

40. Falvik, N.; Nilsson, U. Granskogsbruksmodell (DT) (Model for Norway Spruce Stand (DT)). Available online: http:/ /www-gran.slu.se/Webbok/PDFdokument/GranmodellenMoM.pdf (accessed on 10 September 2015).

41. Söderberg, U. Funktioner för Skogsindelning: Höjd, Formhöjd Och Barktjocklek för Enskilda Träd (Functions for Forest Management: Height, form Height and Bark Thickness of Individual Trees); Institutionen for Skogstaxering: Umea, Sweden, 1992.

42. Elfving, B.; Nyström, K. Growth Modelling in the Heureka System; Department of Forest Ecology and Management, Swedish University of Agricultural Sciences: Umeå, Sweden, 2010; p. 97.

43. Brandel, G. Volume Functions for Individual Trees; Scots Pine (Pinus Sylvestris), Norway Spruce (Picea Abies) and Birch (Betula Pendula \& Betula Pubescens); Swedish University of Agricultural Sciences: Uppsala, Sweden, 1990.

44. Fridman, J.; Ståhl, G. A three-step approach for modelling tree mortality in Swedish forests. Scand. J. For. Res. 2001, 16, 455-466. [CrossRef] 
45. Skogsstyrelsen. Gallringsmallar (Thinning Guides); Skogsstyrelsen: Jönköping, Sweden, 1984; p. 35.

46. Thor, M.; Arlinger, J.D.; Stenlid, J. Heterobasidion annosum root rot in Picea abies: Modelling economic outcomes of stump treatment in Scandinavian coniferous forests. Scand. J. For. Res. 2006, 21, 414-423. [CrossRef]

47. Windmuller-Campione, M.A.; Long, J.N. If Long-Term Resistance to a Spruce Beetle Epidemic is Futile, Can Silvicultural Treatments Increase Resilience in Spruce-Fir Forests in the Central Rocky Mountains? Forests 2015, 6, 1157-1178. [CrossRef]

48. Persson, P. Stormskador på Skog: Uppkomstbetingelser och Inverkan av Skogliga Aatgaerder (Windthrow in Forests: It's Causes and the Effect of Forestry Measures); Rapporter Och Uppsatser/Institutionen Foer Skogsproduktion; Royal College of Forestry: Stockholm, Sweden, 1975; p. 294.

49. Schlyter, P.; Stjernquist, I.; Bärring, L.; Jönsson, A.M.; Nilsson, C. Assessment of the impacts of climate change and weather extremes on boreal forests in northern Europe, focusing on Norway spruce. Clim. Res. 2006, 31, 75-84. [CrossRef]

50. Nilsson, C.; Stjernquist, I.; Bärring, L.; Schlyter, P.; Jönsson, A.M.; Samuelsson, H. Recorded storm damage in Swedish forests 1901-2000. For. Ecol. Manag. 2004, 199, 165-173. [CrossRef]

51. Faustmann, M. Berechnung des Wertes welchen Waldboden sowie noch nicht haubare Holzbestände für die Waldwirtschaft besitzen (Calculation of the Value Which Forest Land and Immature Stands Possess for Forestry). Allg. Forst Jagdztg. 1849, 15, 7-44.

52. Faustmann, M. Calculation of the value which forest land and immature stands possess for forestry. J. For. Econ. (Sweden) 1995, 1, 7-44.

53. Castanheira, P.; Oliveira, J. Land Expectation Value Calculation in Pinus pinaster forestry. In Proceedings of the 21st Annual European Real Estate Society Conference, Bucharest, Romania, 25-28 June 2014.

54. Swedish Forest Agency-Prices-Tables and Figures. Available online: http://www.skogsstyrelsen. se/en/AUTHORITY/Statistics/Subject-Areas/Prices/Tables-and-figures / (accessed on 7 May 2015).

55. Nilsson, U.; Southern Swedish Forest Research Centre, Rörsjövägen 1, Alnarp 230 53, Sweden. Personal Communication, 2015.

56. Rytter, L. Räkna Med hybridasp (Count with hybrid Aspen). Available online: http://www. kunskapdirekt.se/sv/KunskapDirekt/Lov/Verktyg/hybridasp/ (accessed on 7 May 2015).

57. Carbonnier, C.; Hägglund, B. A Comparison between the Volume and Value of the Yield from Beech and Norway Spruce; Royal College of Forestry: Stockholm, Sweden, 1969.

58. Rytter, L.; Stener, L.-G. Growth and thinning effects during a rotation period of hybrid aspen in southern Sweden. Scand. J. For. Res. 2014, 29, 747-756. [CrossRef]

59. Stenlid, J. Controlling and predicting the spread of Heterobasidion annosum from infected stumps and trees of Picea abies. Scand. J. For. Res. 1987, 2, 187-198. [CrossRef]

60. Vollbrecht, G.; Agestam, E. Modelling incidence of root rot in Picea abies plantations in southern Sweden. Scand. J. For. Res. 1995, 10, 74-81. [CrossRef]

61. Yde-Andersen, A. Stump protection with urea against Fomes annosus in Norway spruce. Det Forstl. Forsøgsvæs. Dan. 1982, 38, 209-217.

62. Wermelinger, B. Ecology and management of the spruce bark beetle Ips typographus-A review of recent research. For. Ecol. Manag. 2004, 202, 67-82. [CrossRef]

63. Thor, M.; Ståhl, G.; Stenlid, J. Modelling root rot incidence in Sweden using tree, site and stand variables. Scand. J. For. Res. 2005, 20, 165-176. [CrossRef]

64. Långström, B.; Lindelöw, Å.; Schroeder, M.; Björklund, N.; Öhrn, P. The spruce bark beetle outbreak in Sweden following the January-storms in 2005 and 2007. In Proceedings of the Workshop on "Insect and Fungi in Strom Areas", Štrbské Pleso, Slovakia, 15-19 September 2008; IUFRO: Štrbské Pleso, Slovakia.

65. Lagergren, F.; Jönsson, A.M.; Blennow, K.; Smith, B. Implementing storm damage in a dynamic vegetation model for regional applications in Sweden. Ecol. Model. 2012, 247, 71-82. [CrossRef]

66. Štefančík, I. Development of spruce (Picea abies (L.) Karst.) target (crop) trees in pole-stage stand with different initial spacing and tending regime. J. For. Sci. 2012, 58, 456-464.

67. Rössler, G. The European stem number experiment in Norway spruce (Picea abies (L.) Karst.), 3rd report: Austria (A 18). Ber. Freib. Forstliche Forsch. 2006, 66, 74-86. 
68. Pfister, O.; Wallentin, C.; Nilsson, U.; Ekö, P.-M. Effects of wide spacing and thinning strategies on wood quality in Norway spruce (Picea abies) stands in southern Sweden. Scand. J. For. Res. 2007, 22, 333-343. [CrossRef]

69. Rönnberg, J.; Vollbrecht, G. Early infection by Heterobasidion annosum in Larix $\times$ eurolepis seedlings planted on infested sites. Eur. J. For. Pathol. 1999, 29, 81-86.

(C) 2015 by the authors; licensee MDPI, Basel, Switzerland. This article is an open access article distributed under the terms and conditions of the Creative Commons by Attribution (CC-BY) license (http://creativecommons.org/licenses/by/4.0/). 